\title{
Fuzzy Simple Additive Weighting Method in the Decision Making of Human Resource Recruitment
}

\author{
Budi Prasetiyo ${ }^{\mathrm{a} 1}$, Niswah Baroroh ${ }^{\mathrm{b} 1}$, Dwi Efri Rufiyantia2 \\ aComputer Science Department, FMIPA, Universitas Negeri Semarang, Indonesia \\ Jalan Sekaran, Gunung Pati, Sekaran, Gn. Pati, Kota Semarang, Jawa Tengah \\ 1budipras@mail.unnes.ac.id \\ ${ }^{b}$ Accounting Department, FE, Universitas Negeri Semarang, Indonesia \\ Jalan Sekaran, Gunung Pati, Sekaran, Gn. Pati, Kota Semarang, Jawa Tengah \\ 2barorohniswah@gmail.com
}

\begin{abstract}
The Company is one of the jobs that was founded to reduce unemployment. The progress of a company is determined by the human resources that exist within the company. So, the selection of workers will join the company need to be selected first. The hardest thing in making a selection factor is the effort to eliminate the subjectivity of the personnel manager so that every choice made is objective based on the criteria expected by the company. To help determine who is accepted as an employee in the company, we need a method that can provide a valid decision. Therefore, we use Fuzzy Multiple Attribute Decision Making with Simple Additive Weighting method (SAW) to decide to make in human resource recruitment. This method was chosen because it can provide the best alternative from several alternatives. In this case, the alternative is that the applicants or candidates. This research was conducted by finding the weight values for each attribute. Then do the ranking process that determines the optimal alternative to the best applicants who qualify as employees of the company. Based on calculations by the SAW obtained the two highest ranking results are A5 (alternative 5) and A1 (alternative 1), to obtain two candidates received.
\end{abstract}

Keywords: Fuzzy; Simple Additive Weighting; Human Resource Recruitment

\section{Introduction}

Company as an organization that is driven by Human Resources (HR) confronted with a variety of choices to determine a quality workforce. HR management of a company affects key aspects of the company's business success. If the SDM can be organized well, it is expected that the company can carry out all the processes the business well. To obtain both the human resources, the necessary process of selection is also good. If the company needs new employees, the personnel department needs to select prospective employees by eliminating subjective factors so that every choice made is objective based on the criteria expected by the company. So, with the determination of those criteria, accepted new employees meet the reliable resources and the competitiveness improved management.

Since it was first discovered by Lotfi A. Zadeh in 1965, fuzzy logic has been widely used to help support decision making. One method of fuzzy logic is Fuzzy Multiple Attribute Decision Making (FMADM). Fuzzy Multiple Attribute Decision Making (FMADM) is a method used to find the optimal alternative of a number of alternatives to certain criteria [1]. There are several methods to resolve the problem FMADM, one of which is the Simple Additive Weighting (SAW) [2]. This method was chosen because it can provide the best alternative from several alternatives. Some examples of the use of fuzzy logic in the selection of personnel including Laing and Wang [3], Yaakob and Watada [4], Lovrich [5], and Wang et al. [6], Lazarevic [7]. This paper will discuss the use of SAW method in the decision to HR recruitment. 


\section{Method}

\subsection{Decision Support System}

Decision support system is a system that helps decision-makers to supplement the information from the data that has been processed by the relevant and necessary to make a decision about a problem more quickly and accurately [8]. The purpose of making a decision support system [9], namely:
a. Providing ready for human for decision-making on issues that semi or unstructured.
b. Provide support for decision-making to managers at all levels to help the integration between levels.
c. Improve the effectiveness of managers in decision-making and not an increase inefficiency.

\subsection{Fuzzy Multiple Attributes Decision Making (Fuzzy MADM)}

Basically, the process MADM done through three stages: preparation of the components of the situation, the analysis and synthesis of information. There are several methods that can be used to solve the problem FMADM among others [2]:
a. Simple Additive Weighting Method (SAW)
b. Weighted Product (WP)
c. ELECTRE
d. Technique for Order Preference by Similarity to Ideal Solution (TOPSIS)
e. Analytic Hierarchy Process (AHP)

\subsection{Simple Additive Weighted (SAW)}

Churchman and Ackoff (1945) was first using SAW method to solve the problem of portfolio selection. SAW method widely known and used to solve the problem of multiple attribute decision making (MADM). SAW method is one popular method because of that simplicity [10].

The basic concept Simple Additive Weighted method (SAW) is looking for a weighted sum of the performance rating for each alternative on all attributes. SAW method requires a decision matrix normalization process to a scale that can be compared with all the ratings of existing alternatives [11].

$$
r_{i j}=\left\{\begin{array}{c}
\frac{x_{i j}}{\max _{i} X_{i j}} \text { if } j \text { is benefit attribute } \\
\frac{\min _{i} X_{i j}}{x_{i j}} \text { if } j \text { is cost attribute }
\end{array}\right.
$$

Where rij is the normalized performance rating of alternative $A_{i}$ on $C_{j}$ attributes for each $\mathrm{i}=1,2$, $\ldots, \mathrm{m}$ and $j=1,2, \ldots, n$. Preference value for each alternative $\left(V_{i}\right)$ provided:

$$
V_{i}=\sum_{j=1}^{n} w_{j} r_{i j}
$$

Where:

$V_{i} \quad$ : ranking for each alternative

$w_{j} \quad$ : the weights of each criterion

$r_{i j} \quad$ : the value of normalized performance rating

$V_{i}$ larger value indicates that the selected alternative A_i more.

Steps to resolve Fuzzy MADM using SAW method [2]:

a. Specify the criteria used as a reference for decision making.

b. The rating determines the suitability of each alternative on each criterion.

c. Decide based on the criteria matrix, then normalizing matrix based on the equation adjusted for the type attribute to obtain the normalized matrix $\mathrm{R}$. 
d. The final results obtained from the ranking process is the summation of the matrix multiplication $\mathrm{R}$ normalized with the weight vector to obtain the greatest value is selected as the best alternative as a solution.

\section{Results and Discussion}

Decision making criteria of human resource recruitment are based on:

$\begin{array}{ccl}\text { Criteria } & & \text { Explanation } \\ \text { C1 } & : & \text { Written Exam } \\ \text { C2 } & : & \text { Test Scores Psych test } \\ \text { C3 } & : & \text { Work experience } \\ \text { C4 } & : & \text { Education } \\ \text { C5 } & : & \text { GPA } \\ \text { C6 } & : & \text { Interview }\end{array}$

Giving value of each alternative on predetermined criteria are as follows:

a. Assessment Written Exam

Assessment written exam is based on the assessment criteria test results conducted by the company. The following table (Table 1) categories for the assessment of the written exams were converted into crisp numbers.

Table 1. Written Exam

\begin{tabular}{clc}
\hline $\begin{array}{c}\text { Written } \\
\text { examinations }\end{array}$ & Category & \multicolumn{2}{l}{ Value } \\
\hline $50-$ & Poor & 0,25 \\
59 & Satisfactory & 0,5 \\
$60-$ & & \\
69 & Good & 0,75 \\
$70-$ & Very good & 1 \\
79 & \\
$80-$ & & \\
100 & & \\
\hline
\end{tabular}

b. Psych Test Rate

Assessment test psychological test is the assessment criteria based on test results of psychological test that has the potential employee in the process of a series of tests held company.

c. Work Experience Ratings

Assessment work experience is the assessment criteria based on the experience of the applicants in recognizing the work before applying. Table 2 shows categories for the assessment of work experience who converted to crisp numbers.

Table 2. Work Experience

\begin{tabular}{ccc}
\hline $\begin{array}{c}\text { Work } \\
\text { experience }\end{array}$ & Category & \multicolumn{1}{c}{ Value } \\
\hline $\begin{array}{l}1 \\
\text { years }\end{array}$ & Satisfactory & 0,5 \\
$\begin{array}{l}2-3 \\
\text { years } \\
4\end{array}$ & Good & 0,75 \\
$\begin{array}{c}\text { years } \\
\text { more }\end{array}$ & Very good & 1 \\
\hline
\end{tabular}

d. Assessment of Education

Educational assessment is the assessment criteria made by the company based on the formal education of applicants. Table 3 shows the categories for educational assessment converted into crisp numbers. 
Table 3. Education

\begin{tabular}{rcc}
\hline Education & Category & Value \\
\hline D1 & Poor & 0,25 \\
D3 & Satisfactory & 0,5 \\
S1 & Good & 0,75 \\
S2 & Very good & 1 \\
\hline
\end{tabular}

e. Rating Value GPA

Rate CPI is based on the evaluation criteria of academic achievement of candidates. Categories for the assessment of the GPA are converted into crisp numbers are shown in Table 4.

Table 4. GPA mark

\begin{tabular}{ccc}
\hline GPA & Category & \multicolumn{1}{c}{ Value } \\
\hline $1-$ & Poor & 0,25 \\
1,9 & & \\
$2-$ & Satisfactory & 0,5 \\
2,9 & & \\
3,0 & Good & 0,75 \\
- & & \\
3,4 & Very good & 1 \\
3,5 & & \\
-4 & &
\end{tabular}

f. Assessment Interview

Appraisal interview is the assessment criteria based on the results of the test interviews that have been conducted by the prospective employee in the process of a series of tests held company. Categories for the assessment of the GPA are converted into crisp numbers are shown in Table 5.

Table 5. Assessment interviews

\begin{tabular}{ccr}
\hline Interview & Category & \multicolumn{1}{c}{ Value } \\
\hline $0-$ & Poor & 0,25 \\
49 & & \\
60 & Satisfactory & 0,5 \\
- & & \\
69 & & \\
70 & Good & 0,75 \\
- & & \\
79 & & 1 \\
80 & Very good & 1 \\
100 & & \\
\hline
\end{tabular}

Example of case:

A company in a city require two new employees to be placed at the financial administration. Therefore, companies do recruitment prospective employees by category and a series of tests held company. There are 5 applicants for a job in the company with the results of the data of applicants and applicants test results are shown in Table 6 and Table 7.

Table 6. Applicants candidate

\begin{tabular}{cccc}
\hline Name & Education & GPA & Work experience \\
\hline Eko & S1 & 2,9 & 1 years \\
Andi & D3 & 3,1 & 2 years 3 months \\
Rifki & D1 & 3,5 & 2 years 7 months \\
Adbul & S1 & 3,3 & 1 years \\
Hengki & S2 & 3,4 & 1 years \\
\hline
\end{tabular}


Table 7. Test result

\begin{tabular}{lccc}
\hline Name & $\begin{array}{c}\text { Written } \\
\text { examinations }\end{array}$ & $\begin{array}{c}\text { Psych } \\
\text { test }\end{array}$ & Interview \\
\hline Eko & 79 & 77 & 75 \\
Andi & 68 & 75 & 68 \\
Rifki & 63 & 65 & 65 \\
Adbul & 77 & 79 & 79 \\
Hengki & 85 & 82 & 79 \\
\hline
\end{tabular}

To determine the weighting of the criteria established in Table 8 applicants.

Table 8. Weight for criterion

\begin{tabular}{llc}
\hline \multicolumn{1}{c}{ Criteria } & Weight & $\begin{array}{c}\text { Linguistic } \\
\text { Value }\end{array}$ \\
\hline$\left(C_{1}\right)$ Written Exam & Very good & 0,8 \\
$\left(C_{2}\right)$ Psych Test Scores & Very good & 0,8 \\
$\left(C_{3}\right)$ Work experience & Very good & 0,8 \\
$\left(C_{4}\right)$ Education & Good & 0,75 \\
$\left(C_{5}\right)$ GPA & Satisfactory & 0,5 \\
$\left(C_{6}\right)$ Interview & Satisfactory & 0,5 \\
\hline
\end{tabular}

From Table 8 obtained by the weight values (W) with the data

$W=[0,80,80,80,750,50,5]$

In doing using Simple Additive Weighting Method (SAW), first determine the name of the applicant as an alternative (Table 9).

Table 9. Alternative

\begin{tabular}{lc}
\hline \multicolumn{1}{c}{ Name } & Alternative \\
\hline Eko & $A_{1}$ \\
Andi & $A_{2}$ \\
Rifki & $A_{3}$ \\
Adbul & $A_{4}$ \\
Hengki & $A_{5}$ \\
\hline
\end{tabular}

Once an alternative is determined, then make the rating the suitability of each alternative on each criterion, shown in Table 10.

Table 10. Suitability rating

\begin{tabular}{ccccccc}
\hline \multirow{2}{*}{ Alternative } & \multicolumn{7}{c}{ Criteria } \\
\cline { 2 - 7 } & $C_{1}$ & $C_{2}$ & $C_{3}$ & $C_{4}$ & $C_{5}$ & $C_{6}$ \\
\hline$A_{1}$ & 0,75 & 0,75 & 0,5 & 0,75 & 0,5 & 0,75 \\
$A_{2}$ & 0,5 & 0,75 & 0,75 & 0,5 & 0,75 & 0,5 \\
$A_{3}$ & 0,5 & 0,5 & 0,75 & 0,25 & 1 & 0,5 \\
$A_{4}$ & 0,75 & 0,75 & 0,5 & 0,75 & 0,75 & 0,75 \\
$A_{5}$ & 1 & 1 & 0,5 & 1 & 0,75 & 0,75 \\
\hline
\end{tabular}

From Table 10, the decision matrix obtained as follows.

$$
X=\left(\begin{array}{cccccc}
0,75 & 0,75 & 0,5 & 0,75 & 0,5 & 0,75 \\
0,5 & 0,75 & 0,75 & 0,5 & 0,75 & 0,5 \\
0,5 & 0,5 & 0,75 & 0,25 & 1 & 0,5 \\
0,75 & 0,75 & 0,5 & 0,75 & 0,75 & 0,75 \\
1 & 1 & 0,5 & 1 & 0,75 & 0,75
\end{array}\right)
$$


To normalize the matrix $X$ into matrix $R$ takes the weights of the criteria $(\mathrm{W})$ and multiplied by the matrix $\mathrm{X}$. For the calculation of the matrix $\mathrm{R}$ requires the classification criteria of value added benefit or cost in the Table 11.

Table 11. The classification criteria

\begin{tabular}{lcc}
\hline \multicolumn{1}{c}{ Criteria } & Benefit & Cost \\
\hline$\left(C_{1}\right)$ Written Exam & $\sqrt{ }$ & - \\
$\left(C_{2}\right)$ Psych Test Scores & $\sqrt{ }$ & - \\
$\left(C_{3}\right)$ Work experience & $\sqrt{ }$ & - \\
$\left(C_{4}\right)$ Education & $\sqrt{ }$ & - \\
$\left(C_{5}\right)$ GPA & $\sqrt{ }$ & - \\
$\left(C_{6}\right)$ Interview & $\sqrt{ }$ & - \\
\hline
\end{tabular}

Based on the classification criteria by which all the criteria included in the benefit, the calculation to normalize the matrix $\mathrm{X}$ is as follows.

$$
\begin{aligned}
& R_{11}=\frac{0,75}{\max \{0,75 ; 0,5 ; 0,5 ; 0,75 ; 1\}}=\frac{0,75}{1}=0,75 \\
& R_{21}=\frac{0,5}{\max \{0,75 ; 0,5 ; 0,5 ; 0,75 ; 1\}}=\frac{0,5}{1}=0,5 \\
& R_{31}=\frac{0,5}{\max \{0,75 ; 0,5 ; 0,5 ; 0,75 ; 1\}}=\frac{0,5}{1}=0,5 \\
& R_{41}=\frac{0,75}{\max \{0,75 ; 0,5 ; 0,5 ; 0,75 ; 1\}}=\frac{0,75}{1}=0,75 \\
& R_{51}=\frac{1}{\max \{0,75 ; 0,5 ; 0,5 ; 0,75 ; 1\}}=\frac{0}{1}=1 \\
& R_{12}=\frac{0,75}{\max \{0,75 ; 0,75 ; 0,5 ; 0,75 ; 1\}}=\frac{0,75}{1}=0,75 \\
& R_{22}=\frac{0,75}{\max \{0,75 ; 0,75 ; 0,5 ; 0,75 ; 1\}}=\frac{0,75}{1}=0,75 \\
& R_{32}=\frac{0,5}{\max \{0,75 ; 0,75 ; 0,5 ; 0,75 ; 1\}}=\frac{0,5}{1}=0,5 \\
& R_{42}=\frac{0,75}{\max \{0,75 ; 0,75 ; 0,5 ; 0,75 ; 1\}}=\frac{1}{1}=0,75 \\
& R_{52}=\frac{1}{\max \{0,75 ; 0,75 ; 0,5 ; 0,75 ; 1\}}=\frac{1}{1}=1 \\
& R_{13}=\frac{0,5}{\max \{0,5 ; 0,75 ; 0,75 ; 0,5 ; 0,5\}}=\frac{0,5}{0,75}=0,67 \\
& R_{23}=\frac{0,75}{\max \{0,5 ; 0,75 ; 0,75 ; 0,5 ; 0,5\}}=\frac{0,75}{0,75}=1 \\
& R_{33}=\frac{0,75}{\max \{0,5 ; 0,75 ; 0,75 ; 0,5 ; 0,5\}}=\frac{0,75}{0,75}=1 \\
& R_{43}=\frac{0,5}{\max \{0,5 ; 0,75 ; 0,75 ; 0,5 ; 0,5\}}=\frac{0,5}{0,75}=0,67 \\
& R_{53}=\frac{0,5}{\max \{0,5 ; 0,75 ; 0,75 ; 0,5 ; 0,5\}}=\frac{0,5}{0,75}=0,67 \\
& R_{14}=\frac{0,75}{\max \{0,75 ; 0,5 ; 0,25 ; 0,75 ; 1\}}=\frac{0,75}{1}=0,75 \\
& R_{24}=\frac{0,5}{\max \{0,75 ; 0,5 ; 0,25 ; 0,75 ; 1\}}=\frac{0,5}{1}=0,5 \\
& R_{34}=\frac{0,25}{\max \{0,75 ; 0,5 ; 0,25 ; 0,75 ; 1\}}=\frac{0,25}{1}=0,25 \\
& R_{44}=\frac{0,75}{\max \{0,75 ; 0,5 ; 0,25 ; 0,75 ; 1\}}=\frac{0,75}{1}=0,75 \\
& \operatorname{man}
\end{aligned}
$$




$$
\begin{aligned}
& R_{54}=\frac{1}{\max \{0,75 ; 0,5 ; 0,25 ; 0,75 ; 1\}}=\frac{1}{1}=1 \\
& R_{15}=\frac{0,5}{\max \{0,5 ; 0,75 ; 1 ; 0,75 ; 0,75\}}=\frac{0,5}{1}=0,5 \\
& R_{25}=\frac{0,75}{\max \{0,5 ; 0,75 ; 1 ; 0,75 ; 0,75\}}=\frac{0,75}{1}=0,75 \\
& R_{35}=\frac{1}{\max \{0,5 ; 0,75 ; 1 ; 0,75 ; 0,75\}}=\frac{1}{1}=1 \\
& R_{45}=\frac{0,75}{\max \{0,5 ; 0,75 ; 1 ; 0,75 ; 0,75\}}=\frac{0,75}{1}=0,75 \\
& R_{55}=\frac{0,75}{\max \{0,5 ; 0,75 ; 1 ; 0,75 ; 0,75\}}=\frac{0,75}{1}=0,75 \\
& R_{16}=\frac{0,75}{\max \{0,75 ; 0,5 ; 0,5 ; 0,75 ; 0,75\}}=\frac{0,75}{0,75}=1 \\
& R_{16}=\frac{0,5}{\max \{0,75 ; 0,5 ; 0,5 ; 0,75 ; 0,75\}}=\frac{0,5}{0,75}=0,67 \\
& R_{16}=\frac{0,5}{\max \{0,75 ; 0,5 ; 0,5 ; 0,75 ; 0,75\}}=\frac{0,5}{0,75}=0,67 \\
& R_{16}=\frac{0,75}{\max \{0,75 ; 0,5 ; 0,5 ; 0,75 ; 0,75\}}=\frac{0,75}{0,75}=1 \\
& R_{16}=\frac{0,75}{\max \{0,75 ; 0,5 ; 0,5 ; 0,75 ; 0,75\}}=\frac{0,75}{0,75}=1
\end{aligned}
$$

A matrix obtained as follows.

$$
R=\left(\begin{array}{cccccc}
0,75 & 0,75 & 0,67 & 0,75 & 0,5 & 1 \\
0,5 & 0,75 & 1 & 0,5 & 0,75 & 0,67 \\
0,5 & 0,5 & 1 & 0,25 & 1 & 0,67 \\
0,75 & 0,75 & 0,67 & 0,75 & 0,75 & 1 \\
1 & 1 & 0,67 & 1 & 0,75 & 1
\end{array}\right)
$$

Furthermore, the ranking process done by the sum of the normalized $\mathrm{R}$ matrix multiplication with the weight vector. The ranking result in the Table 12.

$V_{1}=(0,8 \times 0,75)+(0,8 \times 0,75)+(0,8 \times 0,67)+(0,75 \times 0,75)+(0,5 \times 0,5)+(0,5 \times 1)=3,0485$

$V_{2}=(0,8 \times 0,5)+(0,8 \times 0,75)+(0,8 \times 1)+(0,75 \times 0,5)+(0,5 \times 0,75)+(0,5 \times 0,67)=2,885$

$V_{3}=(0,8 \times 0,5)+(0,8 \times 0,5)+(0,8 \times 1)+(0,75 \times 0,25)+(0,5 \times 1)+(0,5 \times 0,67)=2,6225$

$V_{4}=(0,8 \times 0,75)+(0,8 \times 0,75)+(0,8 \times 0,67)+(0,75 \times 0,75)+(0,5 \times 0,75)+(0,5 \times 1)=$ 3,1735

$V_{5}=(0,8 \times 1)+(0,8 \times 1)+(0,8 \times 0,67)+(0,75 \times 1)+(0,5 \times 0,75)+(0,5 \times 1)=3,761$

Table 12. Ranking result

\begin{tabular}{ccc}
\hline Alternative & Value & Rank \\
\hline A1 & 3,0485 & 3 \\
A2 & 2,885 & 4 \\
A3 & 2,6225 & 5 \\
A4 & 3,1735 & 2 \\
A5 & 3,761 & 1 \\
\hline
\end{tabular}

Having obtained the results of two ranks in $V_{5}$ and $V_{4}$ then the best alternative is the $A_{5}$ and $A_{1}$. So, the two candidates received is Hengki $\left(A_{5}\right)$ and Abdul $\left(A_{1}\right)$.

\section{Conclusion}

The determination of employee recruitment is done based on the criteria that have been made by the company. The weights given to each criterion affect the result of determining candidates received. Changes in the value of the weight on a criterion influencing the final calculation. The 
final results obtained from the ranking process with the greatest value is the best alternative as a solution. So, the two candidates received in example case is $A_{5}$ and $A_{1}$.

\section{References}

[1] R. A. P. Youllia Indrwaty, Andriana, "Implementasi Metode Simple Additive Weighting Pada Sistem Pengambilan Keputusan Sertifikasi Guru," Informatika, vol. 2, no. 3, pp. 1-7, 2011.

[2] S. Kusumadewi, S. Hartati, A. Harjoko, and Retantyo Wardoyo, "Fuzzy Multi Attribute Decision Making (FUZZY MADM)," Ed. Pertama Cetakan Pertama. Graha IImu. Yogyakarta., 2006.

[3] G. S. Liang and M. J. J. Wang, "Personnel placement in a fuzzy environment," Computers \& operations research, vol. 19, no. 2, pp. 107-121, 1992.

[4] S. B. Yaakob and J. Watada, "Optimal workers' placement in an industrial environmen," Fuzzy Sets and Systems from Different Perspectives. Studies in Fuzziness and Soft Computing, vol 243, 2009.

[5] M. Lovrich, "A fuzzy Approach to Personnel Selection," 2000.

[6] T. Wang, M.-C. Liou, and H.-H. Hung, "Selection by TOPSIS for surveyor of candidates in organisations," International Journal of Services Operations and Informatics, Vol.1, No.4, pp.332 - 346, 2006.

[7] S. P. Lazarevic, "Personnel Selection Fuzzy Model," International Transactions in Operational Research, vol. 8, no. 1, pp. 89-105, 2001.

[8] S. Nobari, Z. Jabrailova, and A. Nobari, "Using Fuzzy Decision Support Systems in Human Resource Management," International Conference on Innovation and Information Management, 2012, vol. 36, pp. 204-207.

[9] R. Idmayanti, "Sistem Pendukung Keputusan Penentuan Penerima Beasiswa Bbm (Bantuan Belajar Mahasiswa) Pada Politeknik Negeri Padang Menggunakan Metode Fuzzy Multiple Attribute Decision Making," Jurnal Teknologi Informasi \& Pendidikan, vol. 7, no. 1, pp. 18-28, 2014.

[10] J.-J. Huang and G.-H. Tzeng, Multiple attribute decision making: methods and applications. 2011.

[11] W. F. Cascio and H. Aguinis, "Research in industrial and organizational psychology from 1963 to 2007: Changes, choices, and trends.," The Journal of Applied Psychology, Vol. 93, No. 5, pp. 1062-1081, 2008. 